Jurnal Kesehatan Perintis (Perintis's Health Journal) 7 (1) 2020: 51-56

Contents list available at JKP website

Jurnal Kesehatan Perintis (Perintis's Health Journal)

Journal homepage: https://jurnal.stikesperintis.ac.id/index.php/JKP

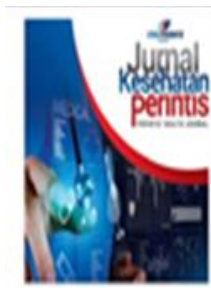

\title{
Potensi Virgin Coconut Oil (VCO) Pada Minyak Herbal Sinergi (MHS)
} Terhadap Ulkus Diabetes

\section{Putri Dafriani ${ }^{\star}$, Niken Niken, Nyak Ramadhani, Roza Marlinda}

Sekolah Tinggi IImu Kesehatan Syedza Saintika, Sumatera Barat, Indonesia

\section{Article Information :}

Submission:Jun 5, 2020; Revised:Jul 1, 2020; Accepted: Jul 1, 2020; Available online: Jul 12,2020

${ }^{*}$ Corresponding author : putridafrianiabd@gmail.com

\begin{abstract}
ABSTRAK
Ulkus DM merupakan salah satu komplikasi DM. Prevalensi Ulkus DM di Indonesia 15\% dengan resiko amputasi 30\%, resiko mortalitas 32\% dan perawatan DM di rumah sakit yang terbanyak (80\%). Perawatan luka dan pemberian antibiotik merupakan bagian dari penatalaksanaan ulkus DM. Ulkus DM sulit sembuh karena resisten dengan antibiotik. Perawatan luka konvensional biasanya menggunakan $\mathrm{NaCl} 0,9 \%$. $\mathrm{NaCl} 0,9 \%$ merupakan salah satu bahan perawatan luka yang biasa dilakukan di rumah sakit. Klien ulkus DM yang kembali ke rumah membutuhkan bahan perawatan luka yang mudah didapatkan. Minyak Herbal Sinergi (MHS) adalah minyak tradisional yang berisikan herbal-herbal yang mengandung antibakteri, antiinflamasi, antioksidan dan antinyeri. Secara umum minyak ini sering dipakai oleh masyarakat sebagai obat luka. Tujuan penelitian ini adalah mempelajari pengaruh MHS terhadap luas ulkus DM. Penelitian ini merupakan penelitian quasy experiment menggunakan 16 responden pasien ulkus DM di Kota Padang. Penelitian ini dilakukan pada bulan Agustus dan September 2019. Responden dibagi menjadi 2 kelompok, 8 orang kelompok kontrol dan 8 orang kelompok intervensi. Perawatan luka dilakukan selama 4 hari dengan menggunakan $\mathrm{NaCl}$ 0,9\%. Pada kelompok intervensi diberikan MHS. Setelah dilakukan perawatan luka selama 4 hari, dilakukan pengukuran luas luka. Perbedaan rata-rata luas luka antar kelompok diuji dengan $t$ test independent. Hasil penelitian didapatkan nilai $p=0,030$ untuk kelompok intervensi, sedangkan untuk kelompok kontrol nilai $p=$ 0,048 . Ini berarti ada pengaruh perawatan luka dengan menggunakan $\mathrm{NaCl} 0,9 \%$ dan minyak MHS. Disarankan kepada klien ulkus DM menggunakan minyak MHS sebagai bagian dari perawatan luka di rumah.
\end{abstract}

Kata kunci : ulkus DM, MHS, VCO, luas luka

\section{ABSTRACT}

DM ulcers are a complication of DM. The prevalence of DM ulcers in Indonesia is $15 \%$ with a $30 \%$ amputation risk, 32\% mortality risk and the highest amount of DM care in hospital (80\%). Wound care and antibiotics are part of the management of DM ulcers. DM ulcers are difficult to cure because they are resistant to antibiotics. Conventional wound care usually uses $0.9 \% \mathrm{NaCl} . \mathrm{NaCl}$ $0.9 \%$ is one of the wound care materials commonly done in hospitals. DM ulcer clients who return home need wound care materials that are easily available. Herbal Sinergi (MHS) oil is a traditional oil that contains herbs that contain antibacterial, anti-inflammatory, antioxidant and anti-pain properties. In general, this oil is often used by people as a wound medicine. The purpose of this study was to study the effect of MHS on DM ulcers. This research is a quasy experiment study 
using 16 respondents of DM ulcer patients in Padang. This research was conducted in August and September 2019. Respondents were divided into 2 groups, 8 control groups and 8 intervention groups. Wound care has given for 4 days. MHS has given for intervention group. $\mathrm{NaCl}$ has given for control group. After wound care for 4 days, the area of the wound was measured. The difference in mean area of wounds between groups was tested by independent $t$ test. The results obtained $p=0.030$ for the intervention group, while for the control group $p=0.048$. This means that there is an effect of wound care using $0.9 \% \mathrm{NaCl}$ and MHS oil. DM ulcer clients are advised to use MHS oil as part of home wound care.

Keywords : ulcer, diabetes, woundcare, MHS

\section{PENDAHULUAN}

Ulkus DM merupakan salah satu komplikasi DM yang diakibatkan oleh gangguan pembuluh darah perifer dan neuropati akibat DM (Dafriani P, 2019). Kondisi ini terjadi pada $15 \%$ dari semua komplikasi DM dengan resiko amputasi 30\%, resiko mortalitas $32 \%$. Klien yang dirawat di rumah sakit dengan ulkus DM mencapai $80 \%$ dari komplikasi DM yang lainnya. Hal ini tentu meningkatkan pembiayaan Kesehatan untuk DM (Handayani, L.T, 2016).

Masuknya bakteri menjadi awal terjadinya ulkus dan kadar gula yang tinggi menjadi tempat yang strategis untuk perkembangan bakteri (Fauji et al, 2018) . Ulkus DM tidak cukup ditangani hanya dengan menggunakan antibiotik, penanganan ulkus DM harus disertai dengan perawatan luka atau rehabilitasi oleh spesialis bedah. Antibiotik hanya cocok untuk luka akut. Ulkus DM merupakan salah satu luka kronik sehingga sering terjadi resistensi antibiotik. Ulkus yang kotor akan menjadi sulit sembuh karena proses inflamasi terus terjadi. Hal ini dapat diperbaiki dengan melakukan perawatan luka.

Salah satu bakteri yang sering menimbulkan infeksi pada Ulkus DM adalah stapylococcus aureus. Bakteri ini membentuk biofilm pada dasar luka sehingga menyulitkan fagositosis dari netrofil. Hal ini menyebabkan bakteri dapat hidup lebih lama dan memperlambat proses penyembuhan luka Putra, A. M., \& Andriani, Y. (2017).

Penyembuhan ulkus terdiri dari beberapa fase, diantaranya adalah fase inflamasi, proliferasi dan remodeling (Sulistianingsih et al, 2014). Luka yang normal akan sembuh selama 7- 10 hari. Lamanya fase penyembuhan luka dipengaruhi oleh banyak faktor, salah satu diantaranya adalah kondisi hiperglikemia. Pada pasien DM penyembuhan luka berlangsung lebih lama.
Perawatan luka merupakan salah satu tindakan keperawatan yang bertujuan untuk memberikan lingkungan yang kondusif agar luka dapat teratasi dengan baik. Perawatan luka modern menemukan bahwa perawatan luka dengan metode lembab jauh lebih efektif untuk penyembuhan luka (Abdo et al, 2020). Selain merangsang granulasi luka, perawatan luka dengan metode lembab juga mencegah terjadinya infeksi. Sejauh ini perawatan luka konvensional masih belum menunjukkan perbaikan jaringan luka yang lebih cepat. Metode perawatan luka menggunakan bahanbahan alam diharapkan mampu mempercepat perbaikan ulkus DM.

Perawatan luka dapat dilakukan dengan menggunakan bahan-bahan yang berasal dari alam (Batool S.H, 2012). Banyak dari bahan alam tersebut mengandung antiinflamasi, antibakteri, antioksidan dan dapat merangsang pertumbuhan kolagen. Penggunaan bahanbahan alam tersebut sudah digunakan secara luas oleh masyarakat, baik untuk tatalaksana luka akut ataupun kronik. Beberapa perawatan luka sudah pernah dilakukan dengan bahan yang memiliki kandungan VCO seperti salep yang mengandung VCO pada ulkus DM (Muktar et al, 2017), penggunaan VCO pada dekubitus (Muflihah et al, 2015) dan penggunaan VCO pada luka bakar (Den Hollander, D (2019). Perbedaan penelitian ini dengan penelitian di atas adalah VCO yang diberikan dalam bentuk gabungan dengan bahan alam lainnya. Penelitian ini belum pernah dilakukan karena VCO digabungkan dengan bahan alam yang banyak terdapat di Indonesia.

Minyak herbal sinergi (MHS) adalah salah satu minyak yang sangat baik untuk perawatan luka. Minyak ini terdiri dari kandungan herbal seperti virgin coconut oil (VCO) (Ibrahim et al, 2013), brotowali(Tinospora cordifolia) , kayu manis (Cinnamomum burmannii), kencur (Kaempferia galanga L)dan sambiloto 
(Andrographis paniculata) (Mollazadeh \& Hosseinzadeh, 2016) .

VCO mengandung antiinflamasi, antipiretik dan memiliki efek analgesik. VCO dapat meningkatkan pembentukan pembuluh darah baru pada luka. Aliran nutrisi dan oksigen yang baik dapat mempercepat penyembuhan luka. Selain itu, VCO juga memiliki kandungan antioksidan yang tinggi yang dapat membantu proses penyembuhan luka. Sebuah studi invitro membuktikan bahwa VCO dapat mengurangi kolonisasi bakteri stapylococcus aureus. Brotowali, kayu manis, dan sambiloto merupakan tumbuhan herbal yang memiliki kandungan flavonoid kuat yang sangat baik sebagai antiinflamasi, antioksidan, antipiretik dan analgesik. Secara tradisional masyarakat sudah banyak menggunakannya sebagai pengobatan untuk berbagai penyakit infeksi (Silalahi et al, 2014). Tujuan penelitian ini adalah untuk mengidentifikasi pengaruh pemberian minyak herbal sinergi (MHS) yang berasal dari VCO, brotowali, kulit manis dan sambiloto terhadap penyembuhan ulkus DM pasien DM di Kota Padang.

\section{METODE PENELITIAN}

\begin{tabular}{llr}
\multicolumn{2}{c}{ Penelitian ini merupakan penelitian } \\
kuantitatif dengan rancangan quasy \\
experiment menggunakan dua kelompok
\end{tabular} responden. Responden adalah pasien ulkus DM yang berada tersebar di Kota Padang. Kriteria inklusi adalah pasien ulkus DM yang sudah dipulangkan dari rumah sakit di Kota Padang, tidak sedang mendapatkan antibiotik dan tidak sedang mendapatkan perawatan luka dari rumah sakit. Penelitian dilakukan pada bulan Agustus dan September 2019. Perawatan luka dilakukan dengan mengunjungi rumah masing-masing responden. Masing-masing kelompok terdiri dari 8 orang responden. Kelompok 1 adalah kelompok kontrol yang diberi perawatan luka dengan menggunakan cairan $\mathrm{NaCl} 0,9 \%$. Kelompok 2 adalah kelompok intervensi yang diberi perawatan luka dengan menggunakan MHS dari Herbal Penawar Al- wahida Indonesia ( $\mathrm{HPAl}$ ). Ulkus DM dibersihkan menggunakan MHS sebanyak 10-30 cc ( sesuai ukuran luka). Masing-masing perawatan luka dilakukan satu kali dalam sehari. Perawatan luka dilakukan selama 4 hari berturut-turut. Luas luka kelompok kontrol dibandingkan dengan luas luka kelompok intervensi setelah diberi perawatan luka dengan menggunakan $t$ test independent. Sebelum dilakukan uji $t$ test independent, dilakukan uji normalitas data dengan menggunakan uji shapiro wilk. Berdasarkan uji shapiro wilk didapatkan nilai $p=0.080$ untuk kelompok kontrol dan $\mathrm{p}=0.092$ untuk kelompok intervensi.

\section{HASIL DAN PEMBAHASAN}

Berdasarkan tabel 1. diperoleh rata-rata luas luka sesudah perawatan luka pada kelompok kontrol. Pada luas luka posttest, mean $3.41 \mathrm{~cm}$, standar deviasi $3.04 \mathrm{~cm}$, nilai minimum $/$ maksimum $0.35 / 10.00 \mathrm{~cm}$.

\section{Tabel 1. Rata-Rata Luas Luka Ulkus DM Setelah Perawatan Luka Pada Kelompok Kontrol}

\begin{tabular}{cccc}
\hline Luas Luka & Mean & SD & Min/Max \\
Post Test & 3,41 & 3,04 & $0,35 / 10,00$ \\
\hline
\end{tabular}

Perawatan ulkus DM terdiri dari tahap pencucian, pembuangan jaringan mati dan pembalutan. Pencucian ulkus DM menggunakan $\mathrm{NaCl}$ 0,9\% dapat mengurangi kotoran dan bakteri pada luka. Pembuangan jaringan yang nekrotik dapat merangsang pertumbuhan jaringan yang baru. Kondisi luka perlu dipertahankan agar tetap lembab agar dapat merangsang percepatan pertumbuhan kolagen dalam fase proliferasi. Berdasarkan karakteristik luka setelah dilakukan perawatan dengan $\mathrm{NaCl} 0,9 \%$, rata-rata luas permukaan luka mengalami penurunan dibandingkan dengan sebelum dilakukan perawatan luka. Penurunan luas permukaan luka $0,1 \mathrm{~cm}^{2}$ selama 4 hari perawatan luka. Setelah dirawat dengan $\mathrm{NaCl}$, pus dan kemerahan berkurang, muncul jaringan granulasi pada pinggir luka. Hal ini terjadi karena jaringan nekrotik pada pinggir ulkus DM sudah diangkat pada saat perawatan luka. $\mathrm{NaCl} 0.9 \%$ juga memberikan lingkungan yang lembab pada luka. Lingkungan yang lembab dapat meningkatkan proses penyembuhan ulkus DM (Abdo et al, 2020).

Berdasarkan tabel 2 pada kelompok intervensi diperoleh rata-rata luas luka sesudah pemberian MHS mean $0.83 \mathrm{~cm}$, standar deviasi $0.533 \mathrm{~cm}$, nilai minimum $/$ maksimum $0.18 / 1.56 \mathrm{~cm}$. 
Perawatan luka pada kelompok intervensi dilakukan dengan membersihkan luka menggunakan MHS. Kandungan minyak dengan mudah melembutkan permukaan kulit yang keras pada pinggir luka.

\section{Tabel 2. Rata-Rata Luas Luka Ulkus DM Sesudah Pemberian MHS Pada Kelompok Intervensi}

\begin{tabular}{cccc}
\hline Luas Luka & Mean & SD & Min/Max \\
Post Test & 0,83 & 0,53 & $0,18 / 1,56$ \\
\hline
\end{tabular}

Kandungan antiinflamasi yang terdapat dalam herbal seperti VCO, brotowali, kencur, kulit manis dan sambiloto meningkatkan penyembuhan luka dengan menurunkan luas permukaan luka. Penurunan luas permukaan luka dengan menambah MHS adalah 0,6 $\mathrm{Cm}^{2}$. Beberapa penelitian lain yang juga menggunakan komposisi herbal tersebut juga memberikan efek yang positif. Kandungan flavanoid dari kulit manis menurunkan kadar TNF- $\alpha$ dan IL-6 yang timbul akibat reaksi makrofag terhadap bakteri yang ada pada luka (Medagama, 2015). VCO juga meningkatkan sirkulasi pada ulkus DM dengan meningkatkan proses angiogenesis, hal ini membuat nutrisi dan oksigen yang dibutuhkan dalam proses penyembuhan luka dapat terpenuhi dengan baik (Dewi et al, 2019).

Hasil uji statistik dengan uji independent $t$ test didapatkan pada kelompok intervensi nilai $\mathrm{p}=0,030$ dan kelompok kontrol $\mathrm{p}=0.048$ berarti $\mathrm{p} \leq 0,05$ (Equal Variances Assumed). Hasil ini dianggap bermakna, berarti ada pengaruh pemberian $\mathrm{NaCl} 0.9 \%$ dan $\mathrm{MHS}$ terhadap luas luka ulkus DM di Kota Padang (tabel 3)

Kemampuan MHS dalam menurunkan luas permukaan ulkus DM sama halnya dengan penggunaan $\mathrm{NaCl} 0.9 \%$ yang digunakan di rumah sakit. Selain itu MHS juga memiliki kandungan yang bermanfaat untuk penyembuhan ulkus DM yang tidak dimiliki oleh $\mathrm{NaCl} 0.9 \%$. MHS yang digunakan pada penelitian ini mengandung berbagai manfaat dalam penyembuhan ulkus DM seperti antiinflamasi, antibakteri, antioksidan, antipiretik dan antianalgesik.

VCO dapat meningkatkan penyembuhan luka karena dapat merangsang angiogenesis dan menekan marker inflamasi

Tabel 3. Perbedaan Rata-Rata Luas Luka Ulkus DM Sesudah Pemberian MHS Pada Kelompok Intervensi dan Kelompok Kontrol

\begin{tabular}{lllcccc}
\hline \multicolumn{1}{c}{ Variabel } & \multirow{2}{*}{ Kelompok } & Mean & SD & \multicolumn{2}{c}{$95 \%$ Cl } & P-Value \\
Post Test & Intervensi & 0,8300 & 0,53388 & $-4,92346$ &,- 23654 & 0,030 \\
Post Test & Kontrol & 3,4100 & 3,04396 & $-5,13364$ &,- 02636 & 0,048 \\
\hline
\end{tabular}

VCO dapat meningkatkan pembentukan pembuluh darah baru pada luka . Aliran nutrisi dan oksigen yang baik dapat mempercepat penyembuhan luka. Selain itu, VCO juga memiliki kandungan antioksidan yang tinggi yang dapat membantu proses penyembuhan luka. Sebuah studi invitro membuktikan bahwa asam laurik yang terdapat pada VCO dapat mengurangi kolonisasi bakteri stapylococcus aureus (Khairunnisa, 2018). Selain itu, asam laurik juga dapat merangsang pertumbuhan kolagen sehingga dapat memperbaiki luka dengan lebih cepat (Aziz et al, 2017).

Brotowali dapat meningkatkan penyembuhan luka pada ulkus DM tikus DM dengan meningkatkan jumlah sel fibroblast. Selain itu brotowali juga bersifat bakteriasid yang dapat menghambat pertumbuhan bakteri. Kulit manis juga memiliki kandungan antiinflamasi yang kuat. Kulit manis dapat menurunkan kadar marker inflamasi seperti TNF- $\alpha$. Berkurangnya inflamasi tergambar dari karakteristik ulkus DM. Kondisi ulkus DM pada kelompok intervensi berbeda dengan kelompok kontrol. Pada kelompok kontrol pus pada luka berkurang karena perawatan dengan $\mathrm{NaCl} 0.9 \%$. $\mathrm{NaCl} 0.9 \%$ merupakan larutan fisiologis yang baik digunakan untuk perawatan luka. Penelitian ini sejalan dengan penelitian Purnomo tahun 2013, hasil penelitian tersebut menjelaskan ulkus DM mengalami perbaikan jaringan. Komposisinya yang sama dengan cairan tubuh menyebabkan luka tidak iritasi. Walaupun begitu cairan $\mathrm{NaCl}$ $0.9 \%$ kurang efektif untuk mencegah 
terbentuknya jaringan nekrotik. Jaringan nekrotik merupakan tempat pertumbuhan bakteri yang baik. (Purnomo et al, 2013). Penggunaan $\mathrm{NaCl} 0.9 \%$ juga dapat meningkatkan penyembuhan luka dibandingkan dengan penggunaan larutan iodin. Sifat cairan fisiologis menyediakan kelembapan yang mempercepat penyembuhan luka (Setyawati et al, 2013). Pada kelompok intervensi tidak hanya pus yang berkurang, tetapi bengkak dan kemerahan pada luka juga berkurang. Karakteristik luka berbeda signifikan dengan luka yang dirawat dengan $\mathrm{NaCl} 0.9 \%$, pada ulkus DM yang menggunakan MHS pinggiran luka lebih kering, pus tidak ada lagi dan jaringan fibroblast sudah mulai terbentuk dipermukaan ulkus DM. Kandungan VCO pada MHS dapat merangsang proliferasi sel fibroblast pada mukosa palatum setelah operasi pada palatoplasy. Pada penelitian tersebut VCO juga mengurangi nyeri pada luka (Rajagukguk et al, 2017). Anti nyeri dan antiinflamasi pada VCO tidak dimiliki oleh cairan $\mathrm{NaCl}$ 0.9\% (Firdaus, R, 2017). Berdasarkan wawancara dan observasi ulkus DM yang mendapatkan MHS, skala nyeri dan udem sudah jauh berkurang. Hal ini menunjukkan bahwa proses inflamasi sudah berkurang.

Reaksi inflamasi biasanya berlangsung sampai 4 hari. Setelah itu berlanjut dengan fase proliferasi yang ditandai dengan pembentukan jaringan fibroblast pada luka. Perawatan luka dengan $\mathrm{NaCl} 0.9 \%$ dan $\mathrm{MHS}$ meningkatkan proses penyembuhan luka terutama pada fase inflamasi dan proliferasi (Susanto et al, 2015). Karena penelitian ini hanya sampai 4 hari maka penyembuhan luka pada fase remodeling tidak dapat diamati. Sarannya untuk penelitian selanjutnya adalah melanjutkan perawatan luka sampai fase remodeling.

\section{KESIMPULAN}

Perawatan luka dengan menggunakan MHS memiliki kemampuan menurunkan luas permukaan luka, sama halnya dengan perawatan luka menggunakan $\mathrm{NaCl} 0,9 \%$. Kelebihan penggunaan MHS adalah mudah didapat dan memiliki kandungan antinyeri dan antiinflamasi sehingga meningkatkan penyembuhan ulkus DM. hal ini karena MHS karena mengandung berbagai senyawa terutama flavonoid yang bersifat antiinflamasi, antibakteri dan antioksidan. Penggunaan MHS dapat dilakukan di rumah bagi klien ulkus DM.

\section{REFERENSI}

Abdo, J. M., Sopko, N. A., \& Milner, S. M. (2020). The applied anatomy of human skin: a model for regeneration. Wound Medicine, 28, 100179.

Aziz, T., Olga, Y., \& Puspita Sari, A. (2017). Pembuatan Virgin Coconut Oil (Vco) Dengan Metode Penggaraman. Jurnal Teknik Kimia, 23(2), 129-136. https://doi.org/10.30998/simponi.v0i0.544

Batool, S. H. (2012). The effect of coconut oil extract on full thickness wound healing on the female rabbit. Basrah Journal of Veterinary Research., 11(2), 28-36.

Dafriani Putri, S. A. N. dan W. M. (2019). Analisis Efek Senam Kaki Terhadap Sensitifitas Kaki pada Pasien Diabetes Di Wilayah Kerja Puskesmas Alai Padang. Jurnal Kesehatan Medika Saintika, 02(09), 72-77.

Den Hollander, D. (2019). Care of the burn patient after the discharge: clinical-wound care. Medical Chronicle, 2019(Sep 2019), 44-44.

Dewi, H. K., Mardiyono, M., Fatmasari, D., Sudirman, S., \& Saha, D. (2019). Effect of Red Fruit Oil Soap (Pandanus Conoideus Lam.) as Wound Cleansing on Wound Healing and the Number of Bacterial Colonies among Grade II Diabetic Ulcer Patients at Griya Wound Care Clinic Kudus, Indonesia. GHMJ (Global Health Management Journal), 3(2), 55-63.

Fauji, A., Sarwati, P., Rahmah, N. M., \& Nirwana, A. S. (2018). Comparative study of effectiveness of wound cleansing solution in diabetic wound care. Indonesian nursing journal of education and clinic (injec), 2(1), 37-41.

Firdaus, R. (2017). Inovasi Salep Vco (Virgin Coconut Oil) Terhadap Proses Penyembuhan Luka Diabetik. MNJ (Mahakam Nursing Journal), 1(2), 65-94.

Ibrahim, A. H., Al-Rawi, S. S., Abdul Majid, A. S., Al-Habib, O., \& Abdul Majid, A. M. (2013). Pro-angiogenic and wound healing potency of virgin coconut oil. Supp. Care Cancer (MASCC), 21, 235.

Khairunnisa, R. (2018). Identifikasi dan Uji Resistensi Staphylococcus Aureus Pada Ulkus Diabetes Melitus Di Rumah Sakit 
Umum Abdoel Moeloek. Universitas Lampung. Skripsi

Luh Titi Handayani. (2016). Studi meta analisis perawatan luka kaki diabetes dengan modern dressing luh titi handayani*. The indonesian journal of health science, $6(2)$, 149-159.

Medagama, A. B. (2015). The glycaemic outcomes of Cinnamon, a review of the experimental evidence and clinical trials. Nutrition journal, 14(1), 108.

Mollazadeh, H., \& Hosseinzadeh, H. (2016). Cinnamon effects on metabolic syndrome: A review based on its mechanisms. Iranian Journal of Basic Medical Sciences, 19(12), 1258-1270. https://doi.org/10.22038/ijbms.2016.7906

Muflihah, U., \& Muflihatin, S. K. (2015). Analisis Praktik Klinik Keperawatan pada Pasien Stroke Non Hemoragik dengan Penggunaan Virgin Coconut Oil (VCO) Untuk Perawatan Luka Dekubitus di Ruang Unit Stroke RSUD Abdul Wahab Sjahranie Samarinda Tahun 2015.

Muktar, M. Z., Rose, L. B. C., \& Amin, K. A. M. (2017, September). Formulation and optimization of virgin coconut oil with Tween-80 incorporated in gellan gum hydrogel. In AIP Conference Proceedings (Vol. 1885, No. 1, p. 020044). AIP Publishing LLC.

Purnomo, S. E. C., Dwiningsih, S. U., \& Prayitno, A. S. (2013). The Effectivence Of Healing Wound By Using Normal Saline (Nacl 0, 9\%) And Hydrogel For Diabetes Mellitus Patinets' With Ulcer At District Of Semarang Hospital. Jurnal Riset Kesehatan, 2(3), 373-382.

Putra, A. M., \& Andriani, Y. (2017). Pengaruh
Penggunaan Madu Dengan Proses Penyembuhan Ulkus Diabetikum Pada Penderita Diabetes Mellitus. Jurnal Kesehatan Perintis, 4(1), 19-25.

Rajagukguk, H., Syukur, S., Ibrahim, S., \& Syafrizayanti, S. (2017). Beneficial Effect of Application of Virgin Coconut Oil (VCO) Product from Padang West Sumatra, Indonesia on Palatoplasty Wound Healing. American Scientific Research Journal for Engineering, Technology, and Sciences (ASRJETS), 34(1), 231-236.

Silalahi, J., Yademetripermata, \& Putra, E. de L. (2014). Antibacterial activity of hydrolyzed virgin coconut oil. Asian Journal of Pharmaceutical and Clinical Research, 7(SUPPL. 2), 90-94.

Sulistianingsih, Runtuboi, D. Y. P., \& Waworuntu, L. V. (2014). Sensitivitas Antibiotik Terhadap Bakteri yang di Isolasi dari Ulkus Diabetika di RSUD Abepura , Kota Jayapura. Jurnal Biologi Papua, 6(2), 53-59.

Susanto, T. D., Sujatno, M., \& Yuwono, H. S. (2015). Efek Antibakteri Virgin Coconut Oil Terhadap Methicillin Resistant Staphylococcus Aureus. Medicus Jurnal Kedokteran Universitas Pelita Harapan $275,4(8)$

Setyawati, L., \& Ariyanti, I. (2013). Perbedaan Penyembuhan Luka Post Partum Post Sectio Caesarea yang dilakukan Perawatan Luka dengan $\mathrm{NaCl} 0,9 \%$ dan Povidon lodine $10 \%$ di RSUD Tugurejo Semarang Tahun 2013. Jurnal Kebidanan, 2(4), 1-9. 